\title{
Business Sustainability: Efforts To Strengthen Sustainability Corporate In Industrial Estate
}

\author{
Sri Sarjana ${ }^{1}$, Nur Khayati ${ }^{2}$, Lis Warini $^{3}$, dan Praswiyati ${ }^{4}$ \\ ${ }^{1}$ Business Management, SMK Negeri 1 Cikarang Barat \\ Email: srisarjana@gmail.com \\ ${ }^{2}$ Sociology and Anthropology, SMA Negeri 1 Cikarang Utara \\ ${ }^{3}$ Linguistic, SMP Negeri 1 Mojosongo \\ ${ }^{4}$ Linguistic, SMP Negeri 2 Polanharjo
}

\begin{abstract}
Regional development and sustainable development can be done through strengthening various business units developed in certain industrial areas. Industrial estate development is expected to be able to refer to sustainable development by taking into account economic, social, ecological functions and complying with applicable regulations to improve business performance in manufacturing industry. The need for sustainable development in management of industrial estates, diversity of business units, and increasing distribution and management of value chains for business units need to be followed up more comprehensive. Integration of transportation, communication and trade networks in the form of modern logistics and supply chain management enables the production and distribution of global systems that can truly change the level of people's welfare. This research was conducted in three best industrial estates in Indonesia to be taken into consideration in development of 14 priority industrial estate outside the island of Java which has been declared by government. Corporate sustainability important to contribution in improving business performance in manufacturing industry, and will get optimal results if fully supported by diversification strategies, supply chain management and innovation strategies. This research is expected to contribute ideas especially related to business in industrial estates and urban development so that it can further increase understanding of the concepts studied through business performance and its impact on the company's sustainability in development of industrial estates.
\end{abstract}

Keywords : corporate sustainability, business performance, sustainable development 


\section{INTRODUCTION}

Asian countries have experienced rapid economic growth since 1980 directed towards service industry. Many industrialized countries in Asia have successfully faced transition in economic globalization. Economic development which is solely intended to pursue economic growth that is often without regard to sustainability of nature and the environment so that it brings negative impacts on nature and also for society. Negative impact of the economic development process can be reduced through implementation of economic development that is environmentally sound so that development that are experiencing now can also be enjoyed by future generations. There are tasks that must be carried out by all countries including developed countries in placing the world economy towards sustainable development and ensuring the results benefit all countries and communities. The process of globalization makes country's economy interdependent through world trade, technology and investment and global distribution of supply chains. Innovation has an important influence on a country's economic development.

Industry is one of the keys to encourage economic growth. Indonesia's economic growth is highly dependent on the industrial sector, especially manufacturing. The unstable development of the manufacturing industry will make it difficult for economic growth to increase. One step to accelerate in increasing economic growth by industrialization. In the appendix to the national industrial policy in the Republic of Indonesia Presidential Regulation No. 28/2008 it is explained that long-term goal of industrial development is to develop industries with the concept of sustainable development based on three inseparable aspects, namely economic development, social development and environment. Competitive strategy is required by every business unit to win competition in uncertain and turbulent business environment (Sarjana \& Khayati, 2018). Global competition requires high speed, accuracy, creativity and consistency to win business through strengthening optimal competitiveness (Sarjana \& Khayati, 2019).

Implications of urban industrial policy are explored by building new industrial zones, developing highly skilled ecosystems, and encouraging multinational networks with the aim of ensuring conditions to enhance urban creativity and development, especially those with diverse business and democratic economic systems (Bailey \& Cowling, 2011). Cities are economic entities, accumulation of economic strength and resources, employment opportunities and business opportunities, political entities, recognized legal entities, government that provides public resources, capacity and leadership (Mallach, 2013). Cities will emerge as transformation leaders in the development of service sector and be able to attract foreign direct investment (Drobniak \& Skowronski, 2012), important contribution as the identity of the city itself and to improve the quality of life (Ertas \& Ozdemir, 2013). City development is related to industrial development while industrial development has to do with city development (Bailey \& Cowling, 2011).

Industrial area is functional area of urban settlements and contribute greatly to urban development in both economic and demographic fields (Nedelea, 2013). Industrial development shows structure that has similarities with industrial estates including industrial clusters and industrial areas (Salonen, 2010). Resources for industries that are formed through cooperation between upstream and downstream companies in industrial chain as very important resources are provided by industrial clusters (Liu \& Hsu, 2011). Industry clusters influence business competition through increased productivity based on company achievements and guide business development and innovation and can encourage new business (MirHoseini \& Ghanbari, 2011). Industrial cities can affect rural populations and important economically and socially (Akbari \& Arzjani, 2011). Sustainable cities are centers of economic activity in capability to support population stability and growth that have distinctive features, institutions, culture or other unique assets, which can be an attraction of community or can be in the form of money from other regions so as to create jobs and business opportunities for residents cities and increasing needs in building urban environments (Mallach, 2013). Sustainable industry refers to final conditions of transformation process in which industry is part of and actively contributes to social, environmental and economic sustainability in nature, and used to refer to process of accelerating planning and providing the changes needed to achieve goals (Taticchi et al., 2013). Post-industrialization is social process that has large impact on condition of city with main characteristics of economic changes that focus on service sector and not on manufacturing, as well as changes in social structure that gives more power and social status to professionals and experts (Pacione, 2009). Post-industrial cities will occur in the era after industrialization where the economic system is based on providing services not on manufacturing products (Parnell \& Oldfield, 2014). A city can be seen physically congested before increasing its economic growth (Pacetti et al., 2012). Industrial estates are designed to support establishment and growth of new companies in certain technologies and industries, companies are based on similar and interconnected competencies where company has place and means that are 
connected to public agencies (Grandori \& Giordani, 2011).

Indonesia ranks $112^{\text {th }}$ out of 178 countries in the world in assessment of environmental performance index which ranks countries that prioritize environmental issues as superior priority in two policy areas, protecting human health from environmental hazards and protecting ecosystems (YCELP, 2014). Ranking of Indonesia's economic growth towards the world based on BPS data in 2014 has experienced ups and downs in the last five years with 32 in 2009 as highest ranking and 60 in 2010 as lowest ranking. Indonesia's human development index, although it has increased from year to year, but increase has not been significant with value of 73.81 in 2013. While economic growth of Bekasi district in the last ten years has not shown significant growth with the lowest growth rate of $5.04 \%$ and highest $6,21 \%$ while in 2012 economic growth was $6.11 \%$ (BPS, 2012).

Focus of problem that has described previously is related to phenomenon so that there is problems namely low environmental performance index as an effort to sustainable development of industrial zones, instability of aspects of economic growth at global and local levels. Indonesian human growth index which needs significant increase in offset global competition. Phenomenon with formulation of a variety of business units in industrial area can be identified as variable diversification strategy. Phenomenon of increasing demand for distribution and management of value chains from upstream to downstream for industrial estate business units is identified as supply chain management variables. Based on the above problem formulation, purpose of this study is to find out diversification strategies, supply chain management, innovation strategies, business performance and company sustainability in Bekasi industrial area.

Focus of the problem that has been described previously is related to the phenomenon so that there is problems namely the low environmental performance index as an effort to sustainable development of industrial zones, instability of aspects of economic growth at global and local levels, Indonesian human growth index which needs a significant increase in offset global competition. The need for sustainable development in the management of industrial estates is variable of sustainable development. Based on the above problem formulation, purpose of this study is to find out diversification strategies, supply chain management, innovation strategies, business performance and company sustainability in Bekasi industrial estate.

\section{LITERATURE REVIEW}

\section{Corporate Sustainability}

Corporate sustainability is business approach that creates value for shareholders in the long run by generating opportunities and managing risks stemming from economic, environmental and social developments. Corporate sustainability as management strategy not only helps businesses maintain prosperity for people and organizations but also to pursue long-term competitive advantage (Mohamed et al., 2014). The goal of corporate sustainability is to develop organizational processes that contribute to corporate sustainability in meeting the needs of present and future generations for internal and external stakeholders (Abid, 2013). Dimensions of corporate sustainability consisting of profits with indicators of prices, share values and investor relations while the dimensions of planet are distinguished in environmental and neighboring indicators and community dimension shows aspects of general management, work environment, safety $\&$ health, diversity, work ethics and globalization, consumers and suppliers (Marrewijk \& Werre, 2014).

Corporate sustainability requires companies to consider the environmental and social consequences of operating core businesses and implementing and maintaining good corporate governance. The sustainability of company is broadly related to transactions that involve collaboration with suppliers. This is mainly due to increasing challenges to environment and social associated with business operations along supply chain that cannot be resolved by each company but can be resolved through collaboration with business partners (Econsense, 2013). Integration of corporate sustainability in business processes has an impact on short-term efficiency, company risk and operations management, in the service sector has more value than the manufacturing sector (Abid, 2013). Corporate sustainability supports the process of accumulating intangible assets, strengthening the company's ability to identify, protect and provide values such as skills and competencies, value of knowledge, legitimacy, trust and reputation among stakeholders (Francesco \& Clodia, 2010). The pathway to adopting the principles of corporate sustainability is directed through organizational culture sustainability orientation (Linnenluecke \& Griffiths, 2010).

Basic idea of sustainable development is based on depreciation that occurs due to current utilization which should be accompanied by form of compensation efforts carried out by exploring the ability to substitute as much as possible scarce and 
limited resources so that the use of natural resources at this time does not sacrifice the right to meet the needs of future generations (Junaidi, 2013). Sustainable development is conscious effort carried out in the context of development by prioritizing aspects of economic, social and environmental balance considerations that prioritize meeting the needs of future (Junaidi, 2013). Sustainable development is an integration between social economy and environmental development which implies economic growth with protection of environmental quality and improvement of lifestyle, standard of living and welfare (Nizamuddin, 2014).

Sustainable development brings together three economic, social and environmental dimensions into energy in improving human quality. The economic dimension in sustainable development continues to focus on growth, equity and stability and includes eco-efficiency. Social dimension includes empowerment, participation, togetherness, mobility, cultural identity, institutional development, and poverty alleviation. Ecological dimension aims at ecosystem integrity, being environmentally friendly and saving natural resources, conserving biodiversity, and being responsive to global issues (Syahri, 2013). Sustainable community development is defined as development that guarantees the future of a society, and will make community healthy and pay attention to each other between stable social and environmental conditions. Sustainable community development emphasizes the potential for creativity and human mind in finding ways to reconcile the long-term social and economic goals of society with obstacles posed by biophysical environment and community demand (Sugandhy \& Hakim, 2009). Sustainable development as human progress in meeting the needs and aspirations of current generations without compromising the ability of future generations to meet their own needs (Okeke et al., 2014). Sustainable development with an environmental perspective is conscious and planned effort that integrates environment including resources, into development process to ensure the ability, welfare and quality of life of present and future generations (Sugandhy \& Hakim, 2009). Work safety and business performance, especially environment and finance as broader concept of sustainability (Hajmohammad \& Vachon, 2014).

Sustainable development has long-term strategic goal to create economic development, protect natural resources and protect environmental sustainability so that future generations can enjoy human resources and natural environment that requires the joint efforts of all humanity (Liwen $\&$ Juan, 2011). Sustainable development is an important concept in the analysis of aspects related to environmental damage issues that have major impact on quality of life and availability of natural resources with involvement of economic, political, technical and social environment (Stanciulescu \& Diaconescu, 2014). Sustainable development can be achieved if nation emphasizes strategic goals and missions because sustainable development is driven by strategic parameters such as job creation and for long-term economic goals (Singh \& Debnath, 2012). Implementation of sustainable development policies is based on local initiatives and requires institutions and participation of local communities (Tonkovic \& Zlatar, 2014). In terms of product policy, organizations that choose to diversify various traditional products will have the possibility to take advantage of opportunities in gaining new competitive advantages (Gheorghe et al., 2013). In order to integrate principles of sustainable development policies in business, retailers can adopt a series of actions aimed at knowing environmental impact of activities carried out, their effects on the behavior of supply chain members and consumer education (Coca et al., 2013). Quality leadership strategy must recommend companies to implement sustainable development (Peters \& Zelewaki, 2013). Sustainable development is complex concept resulting in diversity of interpretations (Mustata et al., 2013).

Current developments tend to be oriented towards economic progress. Results of development that have achieved are not yet comparable to impacts caused such as environmental damage due to excessive exploitation of natural resources. This has caused deterioration in quality of environment which in turn will reduce quality of human life and make development that has been carried out seem to backfire on development itself. Issue of development can be approached with the concept of sustainable development. This concept carries holistic development, which considers all aspects of development, economic, social, environmental, institutional and others as well as in a balanced and integrated manner. Good development is actually development that is not only ideal for present, but is efficient for future generations (BPS, 2014).

Sustainable development is paradigm of society and state in taking a step forward by considering national resources and local interests and demands for continuous improvement (Kasalis $\&$ Kasale, 2014). Sustainable development includes regional aspects and knowledge domains that have impact on survival and existence of future generations (Tsai, 2013). Sustainable development is normative concept to consider and balance ecological and social issues (Eskerod \& Huemann, 
2013). Three main things in sustainable development namely economic, social and environment must have balance (Ciegis et al., 2011). Sustainable development is very important instrument to support urban development (Bajdor, 2012). Focus on sustainability will be able to produce competitive advantages and identify appropriate ways to differentiate products and services (Dabija \& Babut, 2013). In each city, physical development model has great influence on sustainability of development, urban managers and planners must have information on existing physical expansion and spatial planning models for conducting sustainable development models in urban areas (Mobaraki et al., 2012). To realize sustainable development by building and improving the company's internal control system (Jun, 2014). Combine resource capabilities, capacity levels, environmental capabilities and core competencies to get basic structure of sustainable development capabilities (Zhen \& Junwen, 2013).

The sustainable development policy agenda including poverty alleviation, access to clean water, health, protection of natural resources, climate change, sustainable production and consumption consistently appears as priorities at all levels of policy making as well as transportation, waste, energy, land use and environment (Dabla \& Dabla, 2013). Poverty alleviation is the biggest global challenge facing world today and needed in sustainable development. The ultimate goal must be to ensure world development by leading in anticipating global poverty (Rangreji, 2013). Sustainable development requires participation and perspectives from stakeholders despite differences in reconciliation and conflicting values and objectives in getting agreement and coordination as joint step to achieve values synergistically (Dabla \& Dabla, 2013). Sustainability will be possible if every stakeholder is involved and has role to carry it and must be done by whole world to be sure in order to achieve common goals (I, 2013).

The company is expected to play an active role in proposing initiatives and collaborating with partner countries to develop sustainable innovation, limit unfair competition and implement economic policies to satisfy stakeholders, and must be done by maintaining the economic, social and cultural expectations of future generations by respecting environment (Giuseppina et al., 2014). Company must compile sustainable development policy and prepare and submit plan for implementation of sustainable development by changing commitment of sustainable development policies (Kanayo et al., 2013). Collaboration between companies results in effective ways of facing challenges in sustainable development. Sustainable industrial estates are seen as alternative to providing policies in facilitating collaboration between companies, governments and communities (Ruiz et al., 2013). Government has not taken initiative in promoting small companies in creating jobs so as to reduce the industry's potential for growth. Failure of government to realize the importance of small companies in socioeconomic changes in households to reduce poverty, if this is corrected it will hamper sustainable development (Mots'oene, 2014).

Sustainable development is development that considers sustainability in long term which includes social, economic, environmental and institutional aspects to improve human welfare. The social dimension in sustainable development includes poverty reduction, population dynamics, education for community, health improvement, and settlement arrangement. Economic dimension considers aspects of international cooperation, consumption patterns, financial mechanisms, development and environmentally friendly technology. Environmental dimension is related to quality and quantity of water, land, natural resources, atmosphere, and waste. While institutional aspects include the integration of development and environmental policies, science and technology, international legal mechanisms, information in policy making, strengthening of law in the majority group.

\section{Business Performance}

Business performance is measure of performance related to markets such as market share, sales growth, diversification, product development, not only to measure current market but also as the company's position in coming competition (Lijun et al., 2014). New business performance is based on knowledge of market, opportunities in market, and business approach needed to take advantage of an opportunity, and strategic knowledge is needed to achieve success and long-term sustainability (West \& Noel, 2009). Recommendations for improving business performance consists of consider customer needs in company's strategy, measure customer satisfaction regularly, maintain dynamic system for handling customer complaints, identify competitors' strengths and weaknesses regularly, review competitors regularly, company managers allocate regular meetings to discuss competitors, providing information about competitors to other departments, personnel, units and other resources coordinate to create value for customers by coordinating and integrating together, marketing information systems used in company, information about markets 
customers, competitors and environment that is collected regularly, interpret information (Taleghani et al., 2013).

Improved business performance must be considered in order to improve learning orientation in organizations to improve overall performance results. Business partners can benefit by providing examples of learning in order to develop a business culture that encourages overall organizational learning and in doing so can affect overall business performance (Martinette et al., 2014). Customer perspective has the highest influence on business performance, followed by internal process perspective, growth perspective and financial perspective (Sharabati \& Fuqaha, 2014). Theoretical affirmation with focus on improving business performance at all levels both financial, organizational and achieving competitive advantage in market through quality management system (Ghodbane, 2014). Organizational culture and government policy are variables that influence entrepreneurial orientation which will ultimately affect business performance. Organizational culture not only has direct effect on business performance but also has indirect effect through mediation of entrepreneurial orientation. The importance is direct and indirect effects of government policies on business performance through mediating role of entrepreneurial orientation. Improving quality of distribution policies and government regulations is able to encourage business performance improvement (Korry et al., 2013). Business performance has significantly different changes according to proactive operations. In this case, operational function must be able to maintain a proactive attitude when participating in strategic decision making (Rhee \& Mehra, 2013). The importance of human resources as a key component of internal resources in securing competitive advantage and achieving business performance (Samad, 2013).

Manufacturing companies in developing countries are advised to pursue implementation of sustainability strategies based on their capabilities and should be based on strategies that will improve sustainability through increasing resource productivity and increasing business performance and competitive advantage (Russell \& Millar, 2014). Managers can create mechanisms to encourage development of social capital for entrepreneurs by promoting creation and strengthening of relationships that have positive consequences on business performance (Oliveira, 2012). Companies are measuring performance by using financial and non-financial measurements to achieve better business performance. Business performance of manufacturing companies is studied using performance indicators such as profit margin, return on total assets, sales growth, income or labor, and number of assets or labor (Kasie \& Belay, 2013). Contribution of production to business performance is limited to the existence of products or services, suppliers and capacity management. Business performance is not in line with operational performance if market grows slowly or even declines (Losonci \& Demeter, 2013). Significant improvement in business performance can be realized through implementation of holistic total quality management \& total preventive maintenance over a long period of time. TQM-TPM implementation program can successfully facilitate efforts of manufacturing organizations to achieve improved business performance leading to competitive advantage (Kaur et al., 2013).

Application of sustainable production practices is statistically significantly related to business performance. Company at an early stage adopts the practice of sustainability by emphasizing increasing the productivity of resources which has effect of lowering production costs, will support competitiveness of financing and can lead to better business performance (Russell \& Millar, 2014). Company made an acquisition that aims to improve business performance to introduce gradual change into business system by reinventing business system. While success of acquisition is driven by initial motivation that depends on operational achievement and financial synergy, success of acquisition is driven by motivation that depends on radical changes in competitive conditions by identifying lack of resources (Branko \& Dusan, 2013). Small business owners can successfully improve business performance by investing in employee skills training to a certain time limit by continuing to improve their own expertise. So that in the end, this superior business performance is expected to generate more income for small businesses so that profitability and survival in difficult economic conditions (Chinomona, 2013).

\section{Diversification Strategy}

Diversification strategy is growth strategy of corporation in which company expands its operations by moving to different industries (Kuncoro, 2006), company's growth strategy to broaden the scope of business segments in which companies compete (Kessler, 2013), widely used by large companies by adding new businesses related or unrelated to company's core business to increase revenue (Kusmawati, 2008). Diversification can result in improved performance (Jandik \& Makhija, 2005), in different business segments will open up 
new investment opportunities and in life cycle stage of large companies is important strategy in business development, it is recommended that if top management has tendency to use diversification strategy, it must first measure status, strengths and weaknesses, opportunities for threats, and then if diversity is considered suitable for organizational goals then it must expand business with clear visibility (Chirani \& Effatdoost, 2013).

An international diversification strategy is strategy in which company expands sales of goods or services across regions and countries globally to geographical locations or markets that have enormous potential (Hitt et al., 2013). Diversification is a form of business development by expanding number of business and geographical segments or developing variety of diverse products (Harto, 2005). Reasons of diversification is consists of internal drive where conditions within company itself that give signal for diversification caused by awareness that company is no longer able to serve market, and external drive is the encouragement of those who provide opportunities for opening new businesses (Kuncoro, 2006).

To be basis for diversification expansion, a resource must pass several tests. First, these resources must be competitively superior in a new business. Second, resources that will be brought to new business must be a key success factor in business. Third, when entering new business, company must compete with all resources needed to produce products or services. Large resources do not guarantee the success of diversification, especially if company loses on another dimension. A company must have strategy to achieve competitive balance against the resources it does not have which are essential for success in new business. Fourth, although in principle company resources are able to contribute to competitive advantage in new business (Kuncoro, 2006). Diversified companies will place too large investments in business lines with low investment opportunities (Stultz, 1990). Diversification strategy employed can also level risk, and the risk of business does not have total effect on company because it can be offset by returns obtained from other businesses. Companies engaged in one business sector only accept returns from one business, engaged in more than one business will get returns from different sources and can cover risks from other businesses, because every business has risks and returns that are different from each other (Kusmawati, 2008).

\section{Supply Chain Management}

Supply chain is series of companies that perform interrelated functions in procurement of raw materials to deliver goods or services to the hands of customers, and described as series of processes that involve people and materials, with aim is to deliver goods on time, at right price, right location, and in right amount (Simatupang, 2010). Supply chain as entity that is directly involved in upstream and downstream products, services, finance and or information from sources to customers (Mentzer et al., 2001). Supply chain management is the management of relations between upstream and downstream with suppliers and customers to provide superior customer value at lower cost for entire supply chain (Christhoper, 2013). Regulation of management principles that is followed to create successful supply chain is called supply chain management, and supply chain management is also defined as coordination and management of complex networks of activities involved in delivering finished products to end users or customers (Hervani et al., 2005). The principles of supply chain management must have a thorough knowledge of all processes affected by the supply chain, decisions must be made carefully and all aspects of organization must be considered, and one wrong choice in supply chain can jeopardize the organization's future, and must be measured to evaluate performance (Elrod \& Murray, 2013).

Supply chain management contributes to the reduction of inventory and working capital, and creates close relationship between suppliers and customers (Davenport \& Brooks, 2004). Supply chain management is coordination and cooperation between suppliers and customers to share information and exchange goods and services and the purpose is to reduce uncertainties and risks associated with supply chain, and this can contribute to reducing inventory levels and cycle times, improving business processes, and improving customer service, and ultimately increasing profitability and increasing company competitiveness (Turban et al., 2008). Supply chain management as one of the most important success factors in business environment in future where managing the entire supply chain is very challenging and not an easy task because company considers and directs efforts towards information systems such as ERP systems in order to improve supply chain management performance and provide opportunity to gain competitive advantage in global economy (Lambert \& Cooper, 2000). Dimensions of supply chain management include inventory costs, operational costs, product quality, response to changes, rapid reaction to accuracy of information, delivery accuracy, customer response, customer 
satisfaction, speed of information, accuracy of information, information systems network, and connected with scheduling \& production planning (Shatat \& Udin, 2012).

Supply chain management examines more broadly not only processes but series of processes between organizations, includes discussing relationships with suppliers and customers and the use of latest technology in designing systems, guaranteeing quality, delivering goods, and providing services (Simatupang, 2010). Supply chain management contains activities that can facilitate the movement of goods and information flow from raw materials to customer's final destination, and helps companies improve relationship between suppliers and customers to produce high quality products at lower costs (Chuang \& Shaw, 2005), facilitates product movement through supply chain, manages the flow of related information, manages business relationships with customers and suppliers and other partners in supply chain, and creates customer value to achieve customer satisfaction and loyalty (Burca et al., 2005), consists of activities involved in delivering products from raw materials to finished products to deliver to consumers, include sourcing of raw materials and parts, manufacturing and assembly, warehousing and inventory tracking, order reception and order management, distribution in all channels, shipping to customers, and information systems needed to monitor all these activities (Lummus \& Vokurka, 1999).

Main philosophy of supply chain management is to have right product in the right place, at the right price, at the right time, and in the right conditions. Therefore, companies need not only to flow information within company, but also they need to share this right information with right supply chain partners at the right time. In order to achieve these goals, organizations need information systems, such as ERP systems, to facilitate synchronization of entire supply chain and provide timely information to all supply chain partners to help decision making and ultimately achieve customer satisfaction. ERP systems are generally understood as important precursors for supply chain management performance and are very useful tools for improving it (Zheng et al., 2000). Supply chain management seems to ignore the demand part of customer. It is combination of supply chain and demand chain that needs to be integrated to provide or add value to goods and services delivered to customers (Walters, 2006).

Supply chain management is very useful for companies in helping to integrate behavior between suppliers and consumers, sharing information about inventory levels, forecasting, sales, and market strategies between different members of supply chain. Supply chain management also helps in sharing risks and benefits with activities carried out between members. Developing good relationships between supply chain members helps to focus on same goals in serving customers and integrating processes such as delivery of raw materials, production, or distribution of finished products to avoid further problems (Mentzer et al., 2001). Companies with solid supply chain management can reduce operating costs, inventory, product life cycles, time cycles and will increase cash flow, working capital, transaction efficiency, customer service, and timely delivery (Zheng et al., 2000). In supply chain management economics today is considered one of most important and powerful management strategies that have significant impact on business performance, and supply chain management in business is able to provide premium quality products at low prices to attract customers. In fact, supply chain management is an important component for expanding and connecting with suppliers, distributors and retailers in a distribution network where companies can get the best products at the lowest cost and increase profitability and gain competitive advantage in business world (Zheng et al., 2000).

\section{Innovation Strategy}

Innovation strategy is anything that tends to create new markets by increasing value of products or services that aim to influence competition (Yang et al., 2012), strategic tools that can be used to align company resources and capabilities with opportunities in external environment in order to improve survival and long-term success in organizations (Lily \& Juma, 2014), development of new business models and effective introduction of dramatic innovations to market (Wood, 2007). Mobility that arises in accordance with changes in environment and organizational conditions is called strategic innovation (Enayati et al., 2014).

Fundamental innovation strategy is change in company's business model that allows to provide radical innovation value to market (Jacobs \& Heracleous, 2005). Innovation strategy is not only in the sense of creating and implementing complex and predictable mechanisms by organizations, but more on creating conditions which is effective for organizational development (Macaneiro \& Cunha, 2014). Innovation is one of expected outcomes to be created through management and knowledge quality (Omidvara, 2014), a set catalyst for company performance and competitive advantage (Sher \& Yang, 2005), helps existing products 
through updates to extend product life cycle and prevent product degradation (Berenson \& MohrJackson, 1994).

Process innovation factors reflect company's emphasis on innovation in process technology, skills and techniques, organizational systems, and administrative procedures involved in turning inputs into outputs (Pelser, 2014). Product diversification in Indonesia must compete for large areas of international market trends that require an innovation strategy to diversify in supporting market-oriented and innovation-oriented product development. Competitive advantage in entering new markets is enhanced by innovation and improvement in their bargaining position (Yusuf \& Trondsen, 2014). Companies more evaluating economic feasibility relevant to innovation strategies in the institutional context of several countries can be considered suitable for most competitive innovation strategy (Stankevice, 2014). Five main indicators of innovation strategies are aggressive, analytical, futuristic, proactive, risk taking, defensive (Akhlaqh et al., 2013).

Innovation policies play key role in the formulation and implementation of business strategies that are suggested that companies use innovation proactively as competitive tool and key factors that companies must accept technical risks, increase utilization of sophistication for innovation components and number of innovations (Pelser, 2014). Aggressive globalization can increase degree of novelty for innovation, it not only increases competitive advantage but also creates opportunities for organizations to access new and different markets (Amara et al., 2008). Challenge for organizations is not only to increase amount of innovation produced but also to increase the degree of new innovation. Diversity of innovation is proposed to signify broader competence that can be linked to increased competitiveness derived from observations obtained from literature.

Product innovation improved and developed existing products and commercialization of new products. Innovation has strong market focus. Business innovation processes make improvements from existing processes, development and implementation of new processes. Innovation process has major internal focus that requires the development of new competencies and is derived from habits. Company introduces process innovation by enhancing process effectiveness which includes compliance with processes according to customer demand and compliance with processes with strategies and other components of business system and innovation process also helps product innovation in market or to a new company (Zakić et al., 2008).

\section{RESEARCH METHOD}

This type of research is descriptive and verification. Descriptive research aims to obtain an overview of innovation strategies, supply chain management, diversification strategies, business performance and corporate sustainability. Verification research aims to examine the relationship between five variables. Method used in this research is descriptive survey method to describe systematically and accurately facts and characteristics of certain fields as well as an explanatory survey method to conduct hypothesis testing procedures to answer the problem formulation and research objectives. Type of investigation in this study is the type of causality, which is research that shows the direction of relationship between variables based on the construction of research model. Observations using time coverage that is cross-sectional or one shoot, meaning that information or data obtained is the result of research conducted in certain time.

Sources of data in this study were obtained from various manufacturing industry companies that became study sample. In this study, population is all manufacturing business units in Bekasi Regency. Number of large and medium industries in Bekasi Regency was 844 manufacturing industries (BPS, 2012), carried out using Slovin formula approach. So with a population size of 844 and inaccuracy of 5 percent, a required sample size of 272 is obtained. From the sample size above, further sampling is done with simple random sampling technique where each member of population has same opportunity to be chosen as sample taken randomly through drawing system.

To obtain data, data collection techniques are carried out through interviews conducted with several leaders of manufacturing business units and other stakeholders to obtain necessary data and identify and verify phenomena obtained from observation, and questionnaires as measurement tool to collect primary data from all units manufacturing business developed from operationalization of 50 variables with responses in the form of interval scales with answers 1 very low to 5 very high.

Analysis used in this study consisted of descriptive analysis for variables that were qualitative in nature and quantitative analysis in the form of testing hypotheses using statistical tests. By using a combination of two methods of analysis, it is expected to obtain comprehensive solution to 
problem. Descriptive analysis is used to describe each of research variables in order to obtain information about the understanding of leadership for manufacturing business unit on innovation strategies that occur, supply chain management that occurs, diversification strategies, resulting sustainable development and high and low business performance achieved. Quantitative analysis is performed using structural equation models based on variants.

Based on research background, several hypotheses can be formulated as follows:

1. Diversification strategies, supply chain management, innovation strategies have effect on business performance.

2. Diversification strategy, supply chain management, innovation strategy have an effect on the company's sustainability.

3. Business performance has effect on corporate sustainability.

4. The diversification strategy, supply chain management, and innovation strategy, both directly and through business performance have an effect on the company's sustainability.

\section{RESULT AND DISCUSSION}

The following are some of studies that have been carried out regarding relevant research topics or variables. A more detailed list of previous studies that can be collected from various sources includes diversification strategies, supply chain management, diversification strategies, business performance and corporate sustainability. The importance of choosing right competitive strategy is crucial to future development of manufacturing industry (Sarjana \& Khayati, 2018). Comprehensive diversification in the economy and sustainable development strategies to guide the implementation of strategies internally consistent and integrated. Implement strategies and action plans to implement the necessity of diversification quickly with competitive international economy. In the course of success to be achieved must be ready to change or even abandon policies that have proven successful in past and embrace the principle of openness. Basic prerequisites for strategy of economic diversification and sustainable development to achieve success as the need to embrace positive change and have effective impact on short term (GICO, 2008). Pursuing sustainable development is the best way to achieve economic diversification (Watkinson, 2003).
Companies throughout supply chain must take holistic approach to sustainability and pursue structural changes that are broader than those done in general. This is important in international supply chains. Therefore, sustainability paradigm has influence on supply chain and many supply chain decisions have environmental, social, community and broader supply chain impacts (Ravet, 2011). Sustainable development tends to focus on the study of single opposite function or activity in looking at whole chain (Rao \& Holt, 2005). Principles of sustainability that are applied to companies can be successfully transferred to organizations along supply chain considering environmental and social aspects (Econsense, 2013).

Local innovation has played important role in social and economic progress and can prove its importance for long-term sustainable development. Innovation as embodiment, combination or synthesis of original, relevant knowledge is valued as good product, process or new service (UN, 2008). The approach used to study innovation strategies within company is related to the goals of sustainable development. It is very difficult to characterize technologies that are either profitable or unfavorable for sustainable development, innovation process is more relevant criterion than technology itself. Companies that innovate to capture various aspects of innovation process and to identify characteristics of innovations that encourage sustainable development (Gera \& Gu, 2004).

The right innovation strategy can help companies overcome the problems faced regarding efforts to achieve sustainable competitive advantage (Kuratko, 2005). Sustainable development offers organizational framework based on opportunity and respect for human values. Innovation has to do with using changes in ways that better meet human needs and values. The relationship is very clear even though in the absence of market pressure and same language it will be difficult to realize innovations that can come suddenly and have uncertain consequences. Company shows willingness to express what it is fighting for and in turn understands what 
community expects. Companies are actively developing and combining tools to improve performance on three pillars of sustainable development. Companies learn how to stimulate innovation and set focus targets that measure progress and guarantee relationship between value and customers. But there is a lot that needs to be studied and applied especially in getting innovations that address social pillars of sustainable development (Dearing, 2000).

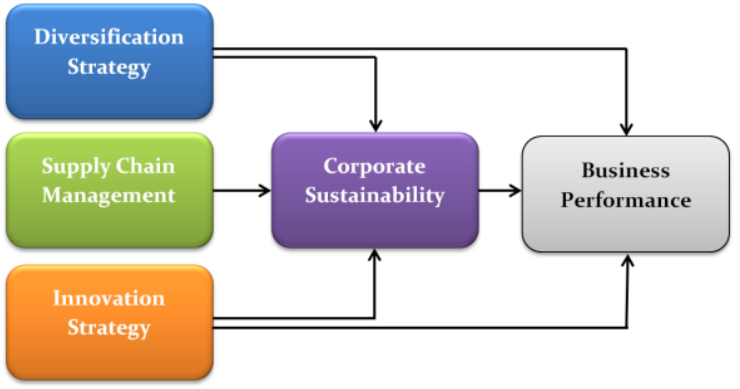

Figure 1. Research Model

Diversification and sustainable growth. It also shows how diversification can reduce the volatility of the nation's economy and improve performance in real activities (Shediac et al., 2008). Functional capabilities in the form of marketing or operations and diversification strategies in the form of products or services and international diversification have significant impact on company's financial performance (Nath et al., 2008). Company does not only look at the perspective of financial activities but must adopt sustainable approach that can strengthen its position in market. Stakeholders especially at regional level must support adoption of sustainable supply chain management practices (Surmacz, 2012).

Diversification both in terms of products or services and geographical areas requires assimilation of broad knowledge in terms of new products and service development, understanding new market cultures and transfer of resources between parent company and partner companies. This is consistent with the RBV literature which highlights efforts to transfer capabilities such as business knowledge between parent and partners is complex process (Fang et al., 2007). Service diversification requires the use of company's strategic resources and functional capabilities across the spectrum of products or services. Regarding diversification of services, portfolio expansion remains within the scope of company's capability resources and can achieve economies of scale and better performance. In terms of servicerelated diversification, scope goes beyond management capabilities and increases costs (Geringer et al., 2000). Social, environmental and economic factors must be taken into account and added to supply chain performance criteria in terms of quality, cost and flexibility. Factors such as purchasing, manufacturing and distribution with an emphasis on environment become common theme in supply chain management, and new term sustainable supply chain management was coined to emphasize change (Carter \& Rogers, 2008). Managers find improvements in business performance through implementation of supply chain management (Sukatil et al., 2013). Supply chain integration has positive impact on business performance and provides benefits for businesses such as information sharing, cost effectiveness, sustainable competitive advantage, customer satisfaction, business renovation, business process modeling and financial performance. Without overcoming and researching challenges related to supply chain integration, it cannot be said that supply chain integration causes better business performance or supply chain integration has positive impact on business performance (Alsagheer, 2011).

Companies that are able to implement complex innovation strategies will achieve better performance (Gera \& Gu, 2004). Two different innovation strategy factors are obtained through analyzes that have been proven to affect company performance and are classified as new product innovations and innovation process factors (Pelser, 2014). Innovation can be seen as goal needed by all companies who want to increase the success of company performance (Varis \& Littunen, 2010). Companies that have innovation strategy are better in terms of productivity compared to companies that are not innovative (Karlsson \& Tavassoli, 2015). Innovation strategies influence factors other than innovation that can improve performance, so that companies that give high priority to research 
and development and implement innovation strategies can produce financially (Nybakk \& Jenssen, 2012).

\section{CONCLUSION}

The concept of corporate sustainability refers to fulfillment for next generation by considering environmental and social consequences in conducting business processes. Therefore, right strategy to produce optimal business performance in manufacturing industry is to consider company's internal and external factors. Strategy aims to achieve best performance in manufacturing is therefore on sustaining the process of improving human well-being (Sarjana, 2015). Contribution in form of novelty to this study is conceptual model of company sustainability in industrial area. Conceptual model of corporate sustainability is directed at improving business performance through optimization in various sectors including diversification strategies, supply chain management, and innovation strategies. Supply chain performance is influential simultaneously and partially to business performance (Mustikaningsih et al., 2019). Competition in manufacturing industry as an effort in development of corporate identity is absolutely done through increase of companies to actively engage in social activities (Sarjana et al., 2018).

This study is expected to contribute thoughts to the world of business management science, especially those related to business in industrial estates and urban development so as to further enhance understanding of concepts studied through business performance and its impact on corporate sustainability in industrial estate development. The concept strategically and comprehensively is that link between scientific world and practical business world can contribute to one another's interdependence. The practical use of this research is expected to be used as input for stakeholders in context of developing industrial estates in the future. Results of this study are expected to be used as reference for evaluating the sustainability of company through business performance in industrial areas that have been and will be conducted throughout Bekasi area.

\section{REFERENCES}

Abid, K. (2013). Integration of Corporate Sustainability With Processes and Its Impact on Corporate Performance. Interdisciplinary Journal of Contemporary Research in Business, 4(9), 863-885.
Akbari, M. R., \& Arzjani, Z. (2011). Nazarabad, a Role Model Industrial Town in Iran (A Case Study). IJBSM, 2(2), 171-172.

Akhlaqh, E. M., Moradi, M., Mehdizade, M., \& Ahmadi, A. D. (2013). Innovation Strategies, Performance Diversity and Development: An Empirical Analysis in Iran Construction and Housing Industry. Iranian Journal of Management Study, 6(2), 31-60.

Alsagheer, A. (2011). Impact Of Supply Chain Integration On Business Performance And Its Challenges. International Business \& Economics Research Journal, 10(12).

Amara, N., Landry, R., Becheikh, N., \& Ouitmet, M. (2008). Learning and novelty of innovation in established manufacturing SMEs. Technovation, 28, 450-463.

Bailey, D., \& Cowling, K. (2011). Rebuilding The City: A Focus For European Industrial Policy. Policy Studies, 32(4), 347-364.

Bajdor, P. (2012). Urban Logistics in Sustainable Development Conception. Valahian Journal of Economic Studies, 3(17), 69-76.

Berenson, C., \& Mohr-Jackson, I. (1994). Product rejuvenation: A less risky alternative to product innovation. Business Horizons, 37(6), 51-57.

BPS. (2012). Kabupaten Bekasi Dalam Angka 2012. BPS Kab Bekasi.

BPS. (2014). Indikator Pembangunan Berkelanjutan 2014. Badan Pusat Statistik.

Branko, R., \& Dusan, M. (2013). Comparative Analysis of Business Performance of Cross Border Acquisitions in Serbia. International Business Research, 6(4).

Burca, S. D., Fynes, B., \& Marshall, D. (2005). Strategic technology adoption: extending ERP across the supply chain. The Journal of Enterprise Information Management, 18(4), 427-440.

Carter, C. R., \& Rogers, D. S. (2008). A framework of sustainable supply chain management: moving toward new theory. International Journal of Physical Distribution \& Logistics Management, 38(5), 360-387.

Chinomona, R. (2013). Business Owner's Expertise, Employee Skills Training And Business Performance: A Small Business Perspective. The Journal of Applied Business Research, 29(6).

Chirani, E., \& Effatdoost, M. (2013). Diversification Strategy, A Way Toward The Competitive Advantage. Kuwait Chapter of Arabian Journal of Business and Management Review, 3(1), 23-27. 
Christhoper, M. (2013). Logistics And Supply Chain Management, 4Th Edition. Prentice Hall.

Chuang, M. L., \& Shaw, W. H. (2005). A roadmap for e-business implementation. Engineering Management Journal, 17(2), 3-13.

Ciegis, R., Kliucininkas, L., \& Ramanauskiene. (2011). Assessment of State and Tendencies of Sustainable Development in Lithuania. Management of Environmental Quality: An International Journal, 22(6), 757-768.

Coca, V., Dobrea, M., \& Vasiliu, C. (2013). Towards a Sustainable Development of Retailing in Romania. Business and Sustainable Development Journal, XV(7), 583-602.

Dabija, D. C., \& Babut, R. (2013). An Approach To Sustainable Development From Tourist Perspective Empirical Evidence in Romania. Business and Sustainable Development, XV(7), 617-633.

Dabla, V., \& Dabla, P. K. (2013). An Insight Into Sustainable Development With Indian \& Global Perspective. Journal of Policy and Organisational Management, 3(1), 22-29.

Davenport, T. H., \& Brooks, J. D. (2004). Enterprise systems and the supply chain. Journal of Enterprise Information Management, 17(1), 8-19.

Dearing, A. (2000). Sustainable Innovation: Drivers and Barriers. OECD TIP workshop.

Drobniak, A., \& Skowronski, M. (2012). Transition and Urban Economic Resilience in Poland's Post-Industrial Cities: The Case of Katowice. Regional Survey, 286(2), 13-15.

Econsense. (2013). Sustainability in Global Supply Chain; Econsense Discussion Paper. Forum for Sustainable Development of German Business.

Elrod, C., \& Murray, S. (2013). A Review of Performance Metrics for Supply Chain Management. Engineering Management Journal, 25(3), 39-50.

Enayati, G., Titkanloo, A. S., \& Mahmouie, A. M. (2014). Strategic Innovation: The Formation And Its Effect on Organization. Indian Journal of Fundamental and Applied Life Sciences, 4(S1), 157-165.

Ertas, S., \& Ozdemir, I. M. (2013). Inner-City Industrial Buildings Finding New Use: The Trabzon Tekel Building. International Journal of Academic Research, 5(2), 126135.

Eskerod, P., \& Huemann, M. (2013). Sustainable Development and Project Stakeholder Management: What Standards Say.
International Journal of Managing Projects in Business, 6(1), 36-50.

Fang, Y., Wade, M., Delios, A., \& Beamish, P. W. (2007). International diversification, subsidiary performance, and the mobility of knowledge resources. Strategic Management Journal, 28, 1053-1064.

Francesco, P., \& Clodia, V. (2010). Corporate Sustainability, Intangible Assets Accumulation and Competitive Advantage Constraints. Emerging Issues in Management, 2, 25-38.

Gera, S., \& Gu, W. (2004). The Effect of Organizational Innovation and Information Technology on Firm Performance. International Productivity Monitor, 9, 37-51.

Geringer, J. M., Tallman, S., \& Olsen, D. M (2000). Product and international diversification among Japanese multinational firms. Strategic Management Journal, 21(1), 51-80.

Gheorghe, G., Nistoreanu, B. G., \& Filip, A. (2013). Traditional Products: Vectors of Sustainable Development on the Regional and National Markets. Business and Sustainable Development, XV(7), 645-658.

Ghodbane, S. B. (2014). The Effect of Quality Management on Business Performance: Case of Tunisian Firms. International Journal of Information, Business and Management, 6(4).

GICO. (2008). A Strategy for Economic Diversification and Sustainable Growth. Bostwana Excellence.

Giuseppina, G., Luisa, B., \& Alex, A. (2014). Risk Management and Sustainable Development of Telecommunications Companies, Symphonya. Emerging Issues in Management, 2, 1-14.

Grandori, A., \& Giordani, L. G. (2011). Organizing Entrepreneurship. Routledge.

Hajmohammad, S., \& Vachon, S. (2014). Safety Culture: A Catalyst for Sustainable Development. Journal Business Ethics, 123, 263-281.

Harto, P. (2005). Kebijakan Diversifikasi Perusahaan dan Pengaruhnya Terhadap Kinerja: Studi Empiris Pada Perusahaan Publik Indonesia. Simposium Nasional Akuntansi.

Hervani, A. A., Helms, M. M., \& Sarkis, J. (2005). Performance Measurement for Green Supply Chain Management. Benchmarking: An International Journal, 12(4), 330-353.

Hitt, M. A., Ireland, R. D., \& Hoskisson, R. E. (2013). Strategic Management: 
Competitiveness \& Globalizations: Concepts, 10th Edition. Cengage Learning.

I, S. (2013). Sustainable Development a Common Goal: Response of Indian Corporates To Meet the World Expectation. Journal of Contemporary Research in Management, 8(1), 17-27.

Jacobs, C. D., \& Heracleous, L. (2005). Answer For Questions To Come: Reflective Dialoque as An Enabler Strategic Innovation. Journal of Organizational Change Management, 18(4), 338-352.

Jandik, T., \& Makhija, A. K. (2005). Can Diversification Create Value? Evidence from the Electric Utility Industry. Financial Management Journal, Spring, 61-93.

Jun, H. (2014). Research on Enterprise's Financial Risks Based on the Theory of Sustainable Development. International Journal of Business and Social Science, 5(4), 280-286.

Junaidi, M. (2013). Korporasi dan Pembangunan Berkelanjutan. Alfabeta.

Kanayo, O., Kizito, E. U., \& Patrick, U. (2013). The Challenges and Implications of Sustainable Development in Africa: Policy Options for Nigeria. Journal of Economic Cooperation and Development, 34(4), 77112.

Karlsson, C., \& Tavassoli, S. (2015). Innovation Strategies And Firm Performance. Cesis Electronic Working Paper Series.

Kasalis, K., \& Kasale, M. (2014). Sustainable Development as Challenge for a Paradigm Shift. Advances In Management, 7(7), 1-8.

Kasie, F. M., \& Belay, A. M. (2013). The Impact of Multi Criteria Performance Measurement on Business Performance Improvement. Journal of Industrial Engineering and Management, 6(2), 595-625.

Kaur, M., Singh, K., \& Ahuja, I. S. (2013). An Evaluation of The Synergic Implementation of TQM And TPM Paradigms on Business Performance. International Journal of Productivity and Performance Management, 62(1), 66-84.

Kessler, E. H. (2013). Encyclopedia of Management Theory. Sage Publication.

Korry, I. N. S., Troena, E. A., Hadiwidjojo, D., \& Noermijati. (2013). The Role of Entrepreneurial Orientation in Mediating the Effect of Organizational Culture and Government Policy toward Business Performance. International Journal of Business and Commerce, 2(12), 29-42.

Kuncoro, M. (2006). Strategi Bagaimana Meraih Keunggulan Kompetitif. Erlangga.
Kuratko, D. F. (2005). A Model of Middle Level Managers' Entrepreneurial Behaviour. Entrepreneurship Theory and Practice, 29, 699-716.

Kusmawati. (2008). Diversifikasi, Kepemilikan Manajerial, dan Kinerja Perusahaan. Jurnal Keuangan Dan Bisnis, 6(1), 12-23.

Lambert, D. M., \& Cooper, M. C. (2000). Issues in supply chain management. Industrial Marketing Management, 29, 65-83.

Lijun, W., Chieh, W. T., Wanchun, D., Hongjuan, Y., \& Sengui, L. (2014). Hair Dressing Entrepreneurs' Motivation, Personality and Business Performance Research. International Journal of Business and Management, 9(7).

Lily, J., \& Juma, D. (2014). Influence of Strategic Innovation on Performance of Commercial Banks in Kenya: The Case of Kenya Commercial Bank in Nairobi County. European Journal of Business Management, 2(2), 1-19.

Linnenluecke, M. K., \& Griffiths, A. (2010). Corporate sustainability and organizational culture. Journal of World Business, 45, 357366.

Liu, H. Y., \& Hsu, C. W. (2011). Antecedents and Consequences of Corporate Diversification: A Dynamic Capabilities Perspective. Management Decision, 49(9), 1510-1534.

Liwen, Z., \& Juan, Z. (2011). Analysis of the Real Estate Enterprise's Core Competitiveness Based on Sustainable Development. Management Science and Engineering, 5(3), $132-134$.

Losonci, D., \& Demeter, K. (2013). Lean Production And Business Performance: International Empirical Results. Competitiveness Review: An International Business Journal, 23(3), 218-233.

Lummus, R. R., \& Vokurka, R. J. (1999). Defining Supply Chain Management: A Historical Perspective and Practical Guidelines. Industrial Management and Data Systems, 99(1), 11-17.

Macaneiro, M. B., \& Cunha, S. K. (2014). Theoretical Analysis Model of the Adoption of Reactive and Proactive Eco-Innovation Strategies: The Influence of Contextual Factors Internal and External to Organizations. Brazilian Business Review, 11(5), 1-23.

Mallach, A. (2013). Sustainability, Social Equity and the Idea of the Good City in PostIndustrial America. Saint Louis University Public Law Review, XXXIII(139), 139-159. 
Marrewijk, M. V, \& Werre, M. (2014). Multiple Levels of Corporate Sustainability. Journal of Business Ethics, 44(2/3), 107-119.

Martinette, L., Leeson, A. O., Gomez, G., \& Webb, J. (2014). Relationship Between Learning Orientation And Business Performance And The Moderating Effect Of Competitive Advantage: An Accounting Services Firm's Perspective. International Business \& Economics Research Journal, 13(4).

Mentzer, J. T., DeWitt, W., Keebler, J. S., Min, S., Nix, N. W., Smith, C. D., \& Zacharia, Z. G. (2001). Defining Supply Chain Management. Journal of Business Logistics, 22(2), 1-25.

MirHoseini, S. V, \& Ghanbari, M. R. (2011). Investigation of the Industrial Clusters in Islamic Republic of Iran: Case Study of Yazd City Using Local Production Systems Method \& Industry Perception Model. International Journal of Academic Research in Business a Nd Social Sciences, 1(3), 357-366.

Mobaraki, O., Mohammadi, J., \& Zarabi, A. (2012). Urban Form and Sustainable Development: The Case of Urmia City. Journal of Geography and Geology, 4(2), 1-12.

Mohamed, R., Jamaluddin, N. A., \& Jamil, C. Z. M. (2014). Corporate Sustainability Drivers And Strategy: Evidence From Malaysian PublicListed Companies. Proceedings of the Australian Academy of Business and Social Sciences Conference.

Mots'oene, K. A. (2014). The Informal Sector and Human Capacity Building For Sustainable Development in Maseru. Journal of Emerging Trends in Economics and Management Sciences, 5(6), 109-114.

Mustata, R. V, Bonaci, C. G., Hintea, C., \& Neamtu, B. (2013). Business Education For Sustainable Development: The Case of Romanian Universities. Business and Sustainable Development, XV(7), 802-818.

Mustikaningsih, D., Cahyandito, M. F., Kaltum, U., \& Sarjana, S. (2019). Building Business Performance through Partnership Strategy Model: Evidence from Renewable Energy Industry in Indonesia. International Journal of Energy Economics and Policy, 9(5), 297307.

Nath, P., Nachiappan, S., \& Ramanathan, R. (2008). The impact of marketing capability, operations capability and diversification strategy on performance: A resource-based view. Industrial Marketing Management, 39, 317-329.

Nedelea, A. D. (2013). Consideration On The Dynamics of Storage Areas and Industrial
Areas in Pitesti City. Geopolitics, History, and International Relations, 5(2), 315-322.

Nizamuddin, M. (2014). Sustainable Development in Gujarat: An Overview. International Journal of Research in Social Sciences, 4(2), 509-521.

Nybakk, E., \& Jenssen, J. I. (2012). Innovation strategy, working climate, and financial performance in traditional manufacturing firms: An empirical analysis. International Journal of Innovation Management, 16(2).

Okeke, R. C., Izueke, E. M. C., \& Nzekwe, F. I. (2014). Energy Security and Sustainable Development in Nigeria. Arabian Journal of Business and Management Review, 4(3), 6372.

Oliveira, J. F. (2012). The Influence of The Social Capital on Business Performance: An Analysis in The Context of Horizontal Business Networks. Adm Mackenzie, 14(3), 209-235

Omidvara, A. (2014). Examining the relationship between knowledge management and innovation level in organizations. Asian Journal of Research in Social Sciences and Humanities, 4(6), 242-252.

Pacetti, M., Passerini, G., Brebbia, C. A., \& Latini, G. (2012). Sustainable City VII: urban Regeneration and Sustainability.

Pacione, M. (2009). Urban Geograph: A Global Perspective, Third Edition. Routledge.

Parnell, S., \& Oldfield, S. (2014). The Routledge Handbook On Cities of the Global South. Routledge.

Pelser, T. G. (2014). Sustaining Industry Leadership Through Innovation Strategy Archetypes. International Business \& Economics Research Journal, 13(4), 697714.

Peters, M. L., \& Zelewaki, S. (2013). Competitive Strategies: Their Relevance for Sustainable Development in the Food Industry. Journal of Management and Sustainability, 3(3), 148157.

Rangreji, F. (2013). The Future We Want: Reflections on The Sustainable Development Paradigm. Environmental Policy and Law, 43(6), 306-317.

Rao, P., \& Holt, D. (2005). Do green supply chains lead to competitiveness and economic performance? International Journal of Operations \& Production Management, 25(9), 898-916.

Ravet, D. (2011). Lean production: the link between supply chain and sustainable 
development in an international environment. Colloque Franco Tchèque 2011.

Rhee, M., \& Mehra, S. (2013). Managing Operational Proactiveness to Facilitate Functional Area Alignment and Enhance Business Performance. Seoul Journal of Business, 19(2).

Ruiz, E. B., Garci'a, M. L. A., \& Kreiner, I. (2013). Analysis of Indicators To Evaluate The Industrial Parks Contribution To Sustainable Development: Mexican Case. Management Research Review, 36(12), 1272-1290.

Russell, S. N., \& Millar, H. H. (2014). Exploring the Relationships among Sustainable Manufacturing Practices, Business Performance and Competitive Advantage: Perspectives from a Developing Economy. Journal of Management and Sustainability, 4(3).

Salonen, T. (2010). Strategies, Structures, and Processes For Network and Resources Management in Industrial Parks: The Cases in Germany and China (p. 14). EUL Verlag.

Samad, S. (2013). Assessing the Contribution of Human Capital on Business Performance. International Journal of Trade, Economics and Finance, 4(6).

Sarjana, S. (2015). Dynamic capabilities in manufacturing: the main role of manufacturing capability, knowledge resources and environmental turbulence to improve enterprise performance. Journal of Entrepreneurship, Business and Economics, 3(2), 41-64.

Sarjana, S., Kartini, D., Rufaidah, P., \& Yunizar. (2018). Reputation Development Strategy for Corporate Operating in Industrial Estate. Academy of Strategic Management Journal, 17(2), 1-12.

Sarjana, S., \& Khayati, N. (2018). Industrial Estate Development: Challenges And Opportunities In Strengthening Competitiveness Of Manufacturing Industries Industrial Estate Development: Challenges and Opportunities in Strengthening Competitiveness of Manufacturing Industries. The Indonesian Journal of Development Planning, II(2), 152169.

Sarjana, S., \& Khayati, N. (2019). Effective Business Strategy: Key to Winning Business Competition in Industrial Estate. Advances in Economics, Business and Management Research, Volume 98, 98(Icot), 53-58.

Sharabati, A. D., \& Fuqaha, S. J. (2014). The Impact of Strategic Management on the Jordanian Pharmaceutical Manufacturing
Organizations' Business Performance. International Review of Management and Business Research, 3(2).

Shatat, A. S., \& Udin, Z. M. (2012). The Relationship Between ERP System and Supply Chain Management Performance in Malaysian Manufacturing Companies. Journal of Enterprise Information Management, 25(6), 576-604.

Shediac, R., Abouchakra, R., Moujaes, C. N., \& Najjar, M. R. (2008). Economic Diversification: The Road To Sustainable Development. Booz \& Company Inc.

Sher, P. J., \& Yang, P. H. (2005). The effects of innovative capabilities and $R \& D$ clustering on firm performance: the evidence of Taiwan's semiconductor industry. Technovation, 25, 33-43.

Simatupang, T. M. (2010). Manajemen Rantai Nilai Dalam Era Kreatif. Majelis Guru Besar ITB.

Singh, R., \& Debnath, R. M. (2012). Modeling Sustainable Development: India's Strategy For the Future. World Journal of Science, Technology and Sustainable Development, 9(2), 120-135.

Stanciulescu, G. C., \& Diaconescu, G. N. (2014). Sustainable Development Seen as Human Evolution: A Modern Approach with Discussion in Tourism. International Journal of Academic Research in Business and Social Sciences, 4(5), 572-582.

Stankevice, I. (2014). Innovation Strategies: The Patterns Across Countries, Industries and Firm Competitiveness. European Scientific Journal, 1.

Stultz. (1990). Managerial discretion and optimal financing policies. Journal of Financial Economics, 26, 3-27.

Sugandhy, A., \& Hakim, R. (2009). Prinsip Dasar Kebijakan Pembangunan Berkelanjutan Berwawasan Lingkungan. Bumi Aksara.

Sukatil, I., Hamid, A. B., \& Baharun, R. (2013). Testing the Effect of the Supply Chain Management Implementation on Business Performance: An Empirical Study. International Business Research, 6(1).

Surmacz, T. (2012). Supply Chain Management and Sustainable Development in Regional Context. University of Rzeszów.

Syahri, M. (2013). Pembangunan Berkelanjutan Berbasis Green Moral. Widya Aksara.

Taleghani, M., Gilaninia, S., \& Talab, S. M. (2013). Relationship between Market Orientation Culture and Business Performance. Interdisciplinary Journal of Contemporary Research in Business, 5(1). 
Taticchi, P., Carbone, P., \& Albino, V. (2013). Corporate Sustainability. SpringerHeidelberg.

Tonkovic, Z., \& Zlatar, J. (2014). Sustainable Development in Island Communities: The Case Study of Postira. European Countryside, 3, 254-269.

Tsai, J. (2013). Strategies for Implementing Education for Sustainable Development in Business Schools. The Journal of Human Resource and Adult Learning, 9(2), 172-183.

Turban, E., Leidner, D., McLean, E., \& Wetherbe, J. (2008). Information Technology for Management: Transforming Organizations in the Digital Economy, 6th ed. Willey \& Sons.

UN. (2008). Innovation For Sustainable Development: Local Case Studies From Africa. United Nations Publication.

Varis, M., \& Littunen, H. (2010). Types of Innovation, Sources of Information and Performance in Entrepreneurial SMEs. European Journal of Innovation Management, 13, 128-154.

Walters, D. (2006). Effectiveness and efficiency: the role of demand chain management. International Journal of Logistics Management, 17(1), 75-94.

Watkinson, P. (2003). EU Perspectives on Economic Diversification for Sustainable Development. EU Pre-sessional Experts Meeting.
West, G. P., \& Noel, T. W. (2009). The Impact of Knowledge Resources on New Venture Performance. Journal of Small Business Management, 47(1), 1-22.

Wood, R. C. (2007). How Strategic Innovation Really Gets Started. Strategy \& Leadership, 35(7).

Yang, X., Jayashree, S., \& Marthandan, G. (2012). Ideal Types of Strategic Innovation: An Exploratory Study of Chinese Cosmetic Industry. International Journal of Business and Management, 7(17).

YCELP. (2014). 2014 Environmental Performance Index: Full Report and Analysis. Yale Center for Environmental Law \& Policy.

Yusuf, M., \& Trondsen, T. (2014). Competitive forces and innovation strategies: a study of the Indonesian crab industries. Journal of Agribusiness in Developing and Emerging Economies, 4(1), 78-96.

Zakić, N., Jovanović, A., \& Stamatović, M. (2008). External And Internal Factors Affecting The Product And Business Process Innovation. Economics and Organization, 5(1), 17 - 29.

Zhen, Y., \& Junwen, F. (2013). Basic Factors Influencing the Sustainable Development Capability of Chinese Property and Casualty Insurance Enterprises. Management Science and Engineering, 7(2), 109-116.

Zheng, S., Yen, D. C., \& Tarn, J. M. (2000). ERP and SCM. Journal of Computer Information Systems, 4l(1), 10. 